$\begin{gathered}\text { EPiC Series in Education Science } \\ \text { Volume 1, 2017, Pages 235-243 }\end{gathered}$
$\begin{gathered}\text { AUBEA 2017: Australasian Universities Build- } \\ \text { ing Education Association Conference 2017 }\end{gathered}$

\title{
A Comparative Study of Traditional and Compressed Scheduling on Undergraduate Construction Students' Performance
}

\author{
$\underline{N, \text { Naismith }}{ }^{l,}$ L,Tookey ${ }^{2}$, J, Tookey \\ ${ }^{1}$ Senior Lecturer, Auckland University of Technology \\ $\underline{{ }^{2} \text { Lecturer, Unitec }}$ \\ nicola.naismith@aut.ac.nz
}

\begin{abstract}
There is a continual need to modify the way tertiary institutions do business to meet the needs of a changing society. The focus has been on success and retention whereas the new strategy in New Zealand supports wider economic growth and prosperity. There is a need for tertiary organisations to think about existing models and means of delivery, inclusive of new and emerging technologies as well as a continued expectation of the ability for tertiary institutions to deliver content via time and cost efficient means. Traditional scheduling involves concurrent enrolment in numerous courses with less contact time over a 16- week timeframe, whereas compressed scheduling focusses on 2 courses per 8 weeks with more instructional time per week. This paper evaluates the use of compressed scheduling methods for first and second year courses on an undergraduate programme in construction in New Zealand. The quantitative study compares end of course exam results, gender, age enrolment and residency status of 2 first year courses and 3 second year courses for the students from 2011 to 2016. The outcomes are consistent with the literature and support the proposition that a similar student learning experience can be achieved in traditional and compressed courses. The findings of the study suggest that concerns associated with offering courses or providing alternative teaching pedagogies associated with traditional and compressed scheduling are unfounded. Interestingly the females in the study performed better in a compressed schedule as compared to a traditional schedule and warrants further research.
\end{abstract}

Keywords: Keywords: Adult Learning, Compressed Scheduling, Construction Student Performance, Traditional Scheduling. 


\section{Introduction}

Tertiary institutions are expected to modify the way they do business in order to meet the needs of a changing society. Historically the focus was on success and retention, however the new strategy highlights the needs of tertiary education to "better equip individuals with the skills and qualifications needed to participate effectively in the labour market (MoE, 2014, p. 2). There is a need for tertiary organisations to think about the existing models and means of delivery, inclusive of new and emerging technologies.

McCoy and Taylor (2000) agree that time problems have caused educators to look at alternatives to the traditional block schedule and that the use of time has been a focus for change in education and education reform. According to Papadakis (2000), making modifications to a schedule will bring about positive changes for the student. However Arnold (2002) feels that administrators have rushed into the adoption of alternative scheduling based on its claimed advantages, but without any real data to support its benefits. Hackmann (2004), suggests that alternative schedules are implemented for a variety of reasons, including stimulating curriculum changes; addressing staffing needs; improving instructional strategies etc. This research study aims to offer insight into how the introduction of compressed blocks of teaching effects student performance, thus providing better understanding and identifying possible areas of improvement. The specific objectives of this study were to:

Establish if the new compressed block scheduling delivery format has influenced student performance.

Establish if, any one group (gender, age, enrolment and residency status) benefits more than another as a result of alternative scheduling methods.

\section{Literature Review}

Widespread reforms, in response to the New Zealand Tertiary Teaching Strategy 2014-2019 has impacted almost every aspect of teaching and learning from examining new teaching methods; emerging technologies and blended learning etc., except how classes are scheduled. Scheduling is the systematic arrangement that brings students, teachers, curriculum, and resources together (Traverso, 1996). More recently it has been described as how often, and for how long a course takes (Dunn and Hooks, 2015).

Clark and Linn (2003) indicate that how much time is allocated, as well as how institutions organise that time in class can impact student learning. Class scheduling can result in courses with timetables that are semester-long (aka traditional), accelerated, intensive or compressed. According to Gallo and Odu (2009) an intensive course means that the number of weeks over which the course is taken is held constant, but the number of days per week on which the course meets, reduces. In a compressed schedule, the number of weeks per term reduces with a corresponding increase in both the number of hours per day and the number of days per week.

Some studies suggest that 'block' teaching often results in better student concentration and better results than in 'traditional' formats (Grant, 2001; Suzan and Paul, 2008; Warburton and Volet, 2013). It is believed that there is an increase in academic achievement for those students enrolled in a block course (Brett, 1996; Deuel, 1999; Hennebry, 1997; Kirby-Smith, 1987; Wlodkowski and Westover, 1999). Other benefits associated with block/compressed scheduling range from improved morale and increased student satisfaction. As well as the enhancement of the quality of the relationship between student and teacher and more lasting relationships with their peers (Hackmann, 2004; Eineder and Bishop, 1997; Fleming et al., 1997; George, 1997; Hughes, 2004; Canady and Rettig, 1996). 
In contrast conducting 'block' courses at undergraduate level raises pedagogical issues relating to time for observation, reflection and long-term content retention (Grant, 2001). It is also suggested that shortened semesters are likely to produce less effective learning as many students forget material and are unable to bridge old and new material (Daniel, 2000; Hamdy and Urich, 1998, Kanun et al., 1963; Wolfe, 1998). Queen (2000) and Rettig and Canady (1997) agree that block/compressed scheduling results in learners having difficulty retaining learning. Arnold (2002) added that any increase in achievement resulting from the implementation of a compressed schedule has diminished by the following year. Lawrence and McPherson (2000) conclude moderate negative impacts on academic performance appear in the areas of language arts, mathematics, social studies, and science.

Other studies suggest that there is little or no change in student achievement when alternative scheduling arrangements are provided (Bottge et al., 2003; Dexter et al., 2006; Zepeda and Mayers, 2006). Carroll, (2003) suggests that the retention of concepts, and process and analytical skills decline slightly whereas Trenta and Newman (2002) suggest mixed results.

The concept that block/compressed scheduling impacts on learning have been discussed. The literature identifies strong advocates and critics and most research available shares both positives and negatives. It is evident from the literature that there is no right or wrong answer, which strongly reinforces the need for this study. It is possible to conclude that learners and educators like block scheduling, but do not know or understand how this effects overall student achievement.

\section{Method}

A longitudinal quantitative study was undertaken in 2016. The research plan focussed on comparing and contrasting the end of exam results obtained on traditional scheduling and compressed block scheduling. It also reviewed whether gender, age, enrolment status or residency status have an impact on overall student performance.

Data was collected retrospectively by academics and administrators and stored securely for statistical analysis. The results were obtained from the institutional administrative information system (PSoft). No individual identifiers are attached to the data providing anonymity and the study was covered by a robust ethical approval at the appropriate tertiary institution (Bryman, 2008; Mutch, 2005).

Data analysis was completed to determine the relationship between student performances on the traditional block as opposed to student performance on the compressed block. The student performance was evaluated via a longitudinal study and group (course by course) analysis. The final end of course exam results (Year 1 and Year 2) were gathered from 2011 - 2013 for the traditional block schedule, and final end of course exam results for the same courses were gathered from 2014 - 2016 for the compressed block schedule. A sample t-test, was conducted to provide a statistical examination of two population means to examine whether the samples are different (Cohen et al., 2011). A $2 \times 2$ independent group design using ANOVA was utilised to examine if any one group benefitted more than another. This analysis examined the variance between groups and results in a p-value which is the probability of obtaining the observed effect under a 'null hypothesis,' which equates to the assumption of 'no difference in the effect of the intervention between studies' (Higgins and Green, 2011). Table 1 outlines the number of students enrolled in the undergraduate construction courses. 
Table 1: Sample size for each course by year and schedule method

\begin{tabular}{|c|c|c|c|c|c|c|c|c|}
\cline { 2 - 9 } \multicolumn{1}{c|}{} & \multicolumn{4}{c|}{ Compressed block schedules } & \multicolumn{3}{c|}{ Traditional block schedules } \\
\hline $\begin{array}{c}\text { Course } \\
\text { / Year }\end{array}$ & 2016 & 2015 & 2014 & Total & 2013 & 2012 & 2011 & Total \\
\hline 1 & 87 & 78 & 82 & 247 & 48 & 65 & 60 & 173 \\
\hline 2 & 91 & 72 & 69 & 232 & 64 & 82 & 70 & 216 \\
\hline 3 & 58 & 65 & 49 & 172 & 53 & 52 & 65 & 170 \\
\hline 4 & 51 & 46 & 55 & 152 & 62 & 60 & 64 & 186 \\
\hline 5 & 67 & 80 & 63 & 210 & 65 & 68 & 71 & 204 \\
\hline
\end{tabular}

\section{Results and Discussion}

Means and standard deviations of the variables can be seen in Table 2. There was a 53\% increase in enrolment in the 2014-2016 period. The enrolment numbers increased over $200 \%$ for students of a traditional age, with a nominal $(1.6 \%)$ increase in adult students. There was a $30 \%$ increase in the male cohort, with a $54 \%$ increase in female students (over the three-year period). With regards to enrolment status, there was a $36 \%$ increase in the number of full-time students with an increase of $26 \%$ for parttime students. $25 \%$ of the increase was a result of domestic enrolments, with an international student body increase of $60 \%$.

The results indicate an average GPA of the full sample $(n=1635)$ was $3.15(\mathrm{C}+)$. The subgroups with the highest GPAs were females on the compressed schedule with 4.05 (B-). Followed by domestic students on the compressed schedule with $3.51(\mathrm{C}+)$, students enrolled part-time on the traditional schedule with $3.38(\mathrm{C}+)$. As well as adults enrolled on a compressed schedule with 3.23 $(\mathrm{C}+)$.

It is interesting to note that the GPA of International Students enrolled on the traditional schedule scored an average GPA of 1.45 compared to those on the compressed schedule with 2.40.

The end of course exam results (see Table 3$)$ for traditional scheduling $(\mathrm{N}=637)$ averaged $58.57 \%$ ( $\mathrm{s}=20.97 \%$ ) over the period 2011-2013. A marginal improvement can be reported for the end of course exam results for compressed scheduling $(\mathrm{N}=976)$ averaged $60.3 \%(\mathrm{~s}=18.95 \%)$ over the 20142016 period (Table XY). 
Table 2: Descriptive statistics for all data

\begin{tabular}{|c|c|c|c|c|c|}
\hline & \multirow[b]{2}{*}{$\mathrm{n}$} & \multicolumn{2}{|l|}{ GPA* } & \multicolumn{2}{|c|}{$\begin{array}{l}\text { End of Course } \\
\text { Exam }\end{array}$} \\
\hline & & $\mu$ & $\begin{array}{l}\text { Std. } \\
\text { Dev. }\end{array}$ & $\mu$ & $\begin{array}{l}\text { Std. } \\
\text { Dev. }\end{array}$ \\
\hline Full sample & 1635 & 3.15 & 2.79 & 59.55 & 19.87 \\
\hline Traditional Schedule (2011-2013) & 644 & 3.08 & 2.87 & 58.48 & 21.07 \\
\hline Compressed Schedule (2014-2016) & 991 & 3.19 & 2.73 & 60.25 & 19.02 \\
\hline Males / Traditional & 549 & 3.10 & 2.87 & 58.47 & 21.19 \\
\hline Males / Compressed & 784 & 2.97 & 2.67 & 58.87 & 18.92 \\
\hline Females / Traditional & 95 & 2.92 & 2.86 & 58.50 & 20.36 \\
\hline Females / Compressed & 207 & 4.05 & 2.80 & 65.40 & 18.53 \\
\hline Less than 25 / Traditional & 136 & 2.65 & 2.64 & 56.28 & 19.89 \\
\hline Less than 25 / Compressed & 475 & 1.72 & 2.29 & 51.80 & 2.29 \\
\hline Adults / Traditional & 508 & 3.19 & 2.91 & 59.07 & 21.33 \\
\hline Adults / Compressed & 516 & 3.23 & 2.73 & 60.47 & 2.73 \\
\hline Full-time / Traditional & 546 & 3.02 & 2.83 & 58.64 & 20.20 \\
\hline Full-time / Compressed & 858 & 3.31 & 2.72 & 61.32 & 18.26 \\
\hline Part-time / Traditional & 98 & 3.38 & 3.06 & 57.56 & 25.38 \\
\hline Part-time / Compressed & 133 & 2.43 & 2.71 & 53.15 & 22.22 \\
\hline Domestic / Traditional & 530 & 3.43 & 2.91 & 60.67 & 21.09 \\
\hline Domestic / Compressed & 707 & 3.51 & 2.76 & 62.27 & 18.92 \\
\hline International / Traditional & 114 & 1.45 & 1.95 & 48.27 & 17.68 \\
\hline International / Compressed & 284 & 2.40 & 2.48 & 55.25 & 18.35 \\
\hline
\end{tabular}

Table 3: Comparison of end of Course Exam results for each scheduling method

\begin{tabular}{|l|l|l|l|}
\hline \multicolumn{2}{|l|}{ Traditional Scheduling } & \multicolumn{2}{l|}{ Compressed scheduling } \\
\hline Mean & 58.57 & Mean & 60.31 \\
\hline Standard Error & 0.83 & Standard Error & 0.61 \\
\hline Median & 60.00 & Median & 62.00 \\
\hline Mode & 0.00 & Mode & 50.00 \\
\hline Standard Deviation & 20.97 & Standard Deviation & 18.95 \\
\hline Sample Variance & 439.75 & Sample Variance & 358.93 \\
\hline Range & 100.00 & Range & 100.00 \\
\hline Minimum & 0 & Minimum & 0 \\
\hline Maximum & 100 & Maximum & 100 \\
\hline Count & 637 & Count & 976 \\
\hline $\mathrm{t}$ & & -1.723 & \\
\hline $\mathrm{p}$ & & 0.085 & \\
\hline
\end{tabular}


Given the findings of this ANOVA comparison test students in compressed scheduling appear to score at a higher level compared to students on the traditional schedule although not at a statistically significant level. To test for the above, a range of null hypothesis were used. After reviewing each, the data for each course and performing ANOVA computations for each course on both schedules, there were some common themes that emerged. After a t-test comparison the results indicated a significant difference in mean scores in three of the five courses, see Table 4.

Table 4 summary of t-test results

\begin{tabular}{|l|l|l|l|}
\hline Course & t-value & $\mathrm{p}$-value & Conclusion \\
\hline 1 & -0.02197 & .982486 & The result is not significant at $\mathrm{p}<.05$ \\
\hline 2 & -1.43967. & .150667 & The result is not significant at $\mathrm{p}<.05$ \\
\hline 3 & -2.30676. & .021671. & The result is significant at $\mathrm{p}<.05$. \\
\hline 4 & 2.67397. & .007874. & The result is significant at $\mathrm{p}<.05$. \\
\hline 5 & -2.9883. & .002959. & The result is significant at $\mathrm{p}<.05$. \\
\hline
\end{tabular}

The results for course 5 are considered to be extremely statistically significant; course 4 are considered to be very statistically significant and course 3 are considered to be statistically significant. This indicates that changing from traditional scheduling to compressed scheduling was a positive move for these three level 6 course.

The findings suggest that concerns associated with offering courses or providing alternative teaching pedagogies associated with traditional and compressed scheduling are unfounded. The outcomes are consistent with the literature and support the proposition that a similar student-learning experience is achieved in traditional and compressed courses. The findings that females perform better in a compressed schedule as opposed to a traditional schedule warrants additional study.

One could argue that the marginal increase in end of course exam results was related to the fact that students only had to remember the subject matter for 8 weeks rather than 16 weeks. If this is a possible explanation, it does not bode well for long life learning or retention of the subject matter. Continued review and reinforcement of content learned in earlier courses could overcome this.

Three main themes emerge from the data for discussion including reasons for entering the industry, the need for gender diversity in the construction industry and issues around entry, progression and retention of women.

\section{Conclusions}

The aim of this study was to establish if there was a difference in student performance as measured by the end of course exam results based on traditional scheduling or compressed block scheduling. The literature suggests mixed reviews on the success of alternative scheduling methods generally. There is indecision on which scheduling method works best. Most of the research conducted discussed the characteristics (positive and adverse) of scheduling methods but very little compared the move from a traditional schedule to a compressed schedule while analysing student achievement results on standardised tests/exams, incorporating gender, age, enrolment status and residency status.

The data from this study provides some answers about the impact of scheduling on end of course exam results and a snapshot of achievement about gender, age, enrolment status and residency status in a New Zealand context. Although the study examined only one undergraduate programme of study over six years, it is believed that the study could be replicated in other contexts 
to test the generalizability of the findings. Further research into the performance of students and scheduling would be valuable in both a New Zealand context and globally.

The purpose of this study was to add to the educational research available and expand the information in the area of scheduling and the effect it has on the end of course exam results. It was not possible to identify which schedule type is better and this warrants further research.

\section{References}

Arnold, D. E. (2002). Block schedule and traditional schedule achievement: A comparison, NASSP Bulletin, Vol. 86, pp. 42-53.

Bottge, B. A., Gugerty, J. J., Serlin, R., and Moon, K. (2003). Block and traditional schedules: Effects on students with and without disabilities in high school. NASSP Bulletin, Vol. 87, pp. 2-14.

Brett, M. (1996). Teaching block-scheduled class periods: A unique educational opportunity. The Education Digest, 62, Vol. pp.34-37.

Bryman, A. (2008). Social research methods (3 ed.). New York: Oxford University Press.

Canady, R L, and Rettig, M D. (1996). All around the block. School Administrator, 53, 8. Retrieved from

http://go.galegroup.com/ps/i.do?id=GALE\%7CA77196545\&v=2.1\&u=per_unit\&it=r\&p=AONE $\& \mathrm{sw}=\mathrm{w}$

Carroll, J. M. (2003). HCI models, theories, and frameworks: Toward a multidisciplinary science. Retrieved from http://unitec.eblib.com.au/patron/FullRecord.aspx?p=294610

Clark, D., and Linn, M. C. (2003). Designing for knowledge integration: The impact of instructional time. Journal of the Learning Sciences, Vol. 12, pp. 451-493. doi:10.1207/ S15327809JLS1204_1

Cohen, L., Manion, L., and Morrison, K. (2011). Research methods in education. (7th ed.). New York, Routledge.

Daniel, E. L. (2000). A review of time-shortened courses across disciplines. College Student Journal, Vol. 34 (2), pp. 298-308.

Deuel, L. S. (1999). Block scheduling in large, urban high schools: Effects on academic achievement, student behaviour, and staff perceptions. The High School Journal, Vol. 83(1), pp. 14-25.

Dexter, K. M., Tai, R. H., and Sadler, P. M. (2006). Traditional and block scheduling for college science preparation: A comparison of college science success of students who report different high school scheduling plans. The High School Journal, Vol. 89(4), pp. 22-33.

Dunn, K., and Hooks, K. (2015). Course scheduling and student learning: An empirical investigation. Global Perspectives on Accounting Education, Vol. 12, pp. 73-95.

Eineder, D. V., and Bishop, H. L. (1997). Block scheduling the high school: The effects on achievement, behavior, and student-teacher, (cover story), NASSP Bulletin, Vol. 81(589), 45.

Fleming, D. S., Olenn, V., Schoenstein, R., and Eineder, D. (1997). Moving to the block: Getting ready to teach in extended periods of time, Washington, D.C.: NEA Publishers.

Gallo, M.A., and Odu, M. (2009). Examining the relationship between class scheduling and student achievement in college algebra, Community College Review, Vol. 36 (4), pp. 299-325. 
George, M. A. (1997). I'd never go back: teachers talk about block scheduling, American Secondary Education, Vol. 25, pp. 23-31.

Grant, D. (2001). Using block courses for teaching logistics, International Journal of Physical Distribution \& Logistics Management, Vol. 31 (7/8), pp. 574-585.

Hackmann, D. G. (2004). Constructivism and block scheduling: Making the connection. Phi Delta Kappan, Vol 85 (9), pp. 697-702.

Hamdy, M., and Urich, T. (1998). Perceptions of teachers in South Florida toward block scheduling. NASSP Bulletin, Vol 82 (596), pp. 79-82.

Hennebry, K. 1997. The impact of class schedule on student performance in a financial management course. Journal of Education for Business, Vol 73 (2), pp. 114-120.

Higgins, J.P.T., and Green, S. (2011). Cochrane Handbook for Systematic Reviews of Interventions Version 5.1.0. (updated March 2011), The Cochrane Collaboration, 2011. Available from www.handbook.cochrane.org.

Hughes, W. W. (2004). Blocking student performance in high school? Economics of Education Review, Vol 23 (6), pp. 663-667.

Kanun, C., Ziebarth, E. W., and Abrahams, N. (1963). Comparison of student achievement in the summer term and regular quarter. Journal of Experimental Education, Vol 32, pp. 123-132.

Kirby-Smith, J. (1987). Effects of intensive college courses on student cognitive development, academic standards, student attitudes and faculty attitudes (Unpublished doctoral dissertation). University of Southern California.

Lawrence, W. W., and McPherson, D. D. (2000). A comparative study of block scheduling and traditional scheduling on academic achievement. Journal of Instructional Psychology, Vol. 27 (3), pp. 178-182.

McCoy, M.H., Taylor, D.L. (2000). Does block scheduling live up to its promise? Paper presented at the annual meeting of the American Educational Research Association New Orleans, April 25, $2000 . \quad$ Retrieved from http://eric.ed.gov/ERICDocs/data/ericdocs2sq1/content_storage_01/0000019b/80 16/4f/c.pdf

Ministry of Education. (2014). Tertiary education strategy: 2014-2019. Retrieved from http://www.education.govt.nz/assets/Documents/Further-education/Tertiary-EducationStrategy.pdf

Mutch, C. (2005). Doing educational research: A practitioner's guide to getting started. Wellington, New Zealand: NZCER Press.

Papadakis, K. (2007). How is a student's learning affected by their school schedule? Retrieved from http://www.csun.edu/ kp797909/646/coursework/files/Action\%20Research\%20Paper.doc

Queen, J. A. (2000). Block scheduling revisited. Phi Delta Kappan, Vol. 82 (3), pp. 214-223.

Rettig, M., and Canady, R. (1997). All around the block schedule. Education Digest, Vol. 62 (6), pp. $30-43$.

Suzan, B., and Paul, L. N. (2008). Block or traditional? An analysis of student choice of teaching format. Journal of Management \& Organization, Vol. 14 (1), pp. 4-19.

Traverso, H. (1996). New directions in scheduling the secondary school. Reston, VA: NASSP. 
Trenta, L., and Newman, I. (2002). Effects of a high school block scheduling program on students: a four-year longitudinal study of the effects of block scheduling on student outcome variables. American Secondary Education, Vol. 31 (1), pp. 54-71.

Warburton, N., and Volet, S. (2013). Enhancing self-directed learning through a content quiz group learning assignment. Active Learning in Higher Education, Vol. 14 (1), pp. 9-22. doi: $10.1177 / 1469787412467126$

Wlodkowski, R. J. and Westover, T. N. (1999). Accelerated courses as a leaning format for adults. Canadian Journal for the Study of Adult Education, Vol. 13 (1), pp. 1-20.

Wolfe, A. 1998. How a for-profit university can be invaluable to the traditional liberal arts. The Chronicle of Higher Education, Vol. 44 (4), B4-B5.

Zepeda, S. J., and Mayers, R. S. (2006). An analysis of research on block scheduling. Review of Educational Research, Vol. 76 (1), pp. 137-170 